\section{P245 GETTING HERPES SIMPLEX: DIAGNOSIS, TREATMENTS AND ATTITUDES OF PATIENTS AND PARTNERS}

Marian Nicholson. Herpes Viruses Association, London, UK

\subsection{6/sextrans-2016-052718.291}

Background/introduction In 2003, a survey summary taken from patients with genital herpes, based on 198 responses was presented to BASHH. In 2015 similar questions were asked, with 548 replies.

Aim(s)/objectives Answers related to place of diagnosis (GP, GUM, etc.), treatments and psychological implications for patients and potential partners. Where the same question was asked in 2003, comparisons with before and after 2003 are made; also male/female. Neuropathic pain resulting from herpes simplex is not widely recognised. Questions re long-term pain have been included in 2015 questionnaire to assess the problem in this self-selected group.

Methods A SurveyMonkey to $800+$ patients: diagnosed 19762015. Questions include where diagnosed, treatment used (e.g. suppression), have symptoms relocated, is there pain? Also level of psycho-sexual burden felt, telling partners and outcome?

Results Diagnosis: $2003,26.8 \%$ by GPs; $53.5 \%$ direct to GUM. 2015, 25.5\% going to GPs, 68.1\% direct to GUM. Access to antivirals: 2003, 21\% (n.42) - mixed episodic/suppressive treatment. 2015, greater usage: episodic treatment 33\% (n.161), suppression $25.4 \%$ (n.139). 11.3\% buy antivirals online. $22.6 \%$ get antivirals from GUM, 34.9\% from GPs. 8.4\% have been refused antivirals by GPs, $8.1 \%$ refused by GUMs. Most also use complementary therapy including $59.5 \%$ making dietary changes. Itching, shooting, aching and other pains before outbreaks $61 \%$, at any time $32 \% 57.7 \%$ actively seek changed mental attitude. $81.8 \%$ have told partner(s) with $82.5 \%$ success rate.

Discussion/conclusion There are limited opportunities for following herpes simplex patients long-term. As well more patients using antivirals, there is a high level of self-help, physical and psychological. Associated neuropathy is high.

\section{P246 PERSISTENCE OF CHLAMYDIAL GENITAL INFECTION - HOW COMMON IS IT?}

1'Jyoti Dhar*, 'Helen Colver, ${ }^{2}$ Patrick Horner. ${ }^{1}$ SSOTP, Leicester, UK; ${ }^{2}$ University of Bristol, Bristol, UK

\subsection{6/sextrans-2016-052718.292}

Background/introduction We present a case of long term persistence of urethral chlamydia in a patient for over 1year, despite multiple treatments. We have not found any such case documented in the literature.

Aims/Objective This case raises certain questions? Could this be happening more often in patients? If yes, what is the significance? May this also explain why CT-positive patients are more likely to re-test positive within 2 yrs?

Methods In Jan 2015 a Slovakian man and his Czech female partner attend for asymptomatic sexual health screen. They were diagnosed with urethral and cervical Chlamydial infection respectively and were treated with a stat dose of Azithryomycin1gm. The only history of note is the female had had treatment for UTI requiring prolonged Nitrofurantion and the male CSW contact 3 yrs ago. No other sexual partners were reported. Rescreen in March 2015 showed persistence of chlamydial urethral infection in the man while the female partner was negative.
Results

\begin{tabular}{|c|c|c|c|c|}
\hline Case & Date & Site tested & Result & $A / B$ used \\
\hline $\begin{array}{l}\text { Male } \\
\text { Female }\end{array}$ & 20.03 .15 & $\begin{array}{l}\text { Urine Vaginal } \\
\text { swab }\end{array}$ & Positive Negative & $\begin{array}{l}\text { Doxycycline } 100 \mathrm{mg} \text { bd } \\
\times 1 / 52 \text { Doxycycline } \\
100 \mathrm{mg} \text { bd } \times 1 / 52\end{array}$ \\
\hline $\begin{array}{l}\text { Male } \\
\text { Female }\end{array}$ & 25.07 .15 & $\begin{array}{l}\text { Urine Vaginal } \\
\text { swab }\end{array}$ & Positive Negative & \\
\hline Male & 25.09 .15 & Urine & Positive & \\
\hline $\begin{array}{l}\text { Male } \\
\text { Female }\end{array}$ & 14.10 .15 & $\begin{array}{l}\text { Urine* }^{*} \\
\text { Urethral } \\
\text { swab }^{*} \text { ("STBRL }^{*} \\
\text { PHE) } \\
\text { vaginal/oral/ } \\
\text { rectal }\end{array}$ & $\begin{array}{l}\text { Positive - LGV DNA not } \\
\text { detected Negative } \\
\text { Negative }\end{array}$ & $\begin{array}{l}\text { Azithromycin 1gm stat, } \\
500 \mathrm{mg} \mathrm{BD} \times 4 / 7\end{array}$ \\
\hline Male & 04.12 .15 & Urine & Positive & Cinnamon and ginger!!! \\
\hline Male & 18.01.16 & $\begin{array}{l}\text { Urine Cell } \\
\text { culture (PHE) } \\
\text { Urethral swab }\end{array}$ & $\begin{array}{l}\text { Equivocal first extraction low } \\
\text { positive, repeat negative } \\
\text { Negative Negative }\end{array}$ & \\
\hline Male & 29.02 .16 & $\begin{array}{l}\text { Urine Urethal } \\
\text { swab }\end{array}$ & Negative Negative & \\
\hline
\end{tabular}

Conclusion Whilst untreated cases of chlamydial infection can resolve, to our knowledge this is the first case of persistent low load infection in a treated case and so is intriguing. It is unlikely to represent residual DNA after such a long period as in this case. The clinical significance of this is uncertain as he remained asymptomatic. The female partner was cured suggesting its not related to genotype and rectal carriage was excluded.

\section{P247 CAN TEXT MESSAGES INCREASE SAFER SEX BEHAVIOURS IN YOUNG PEOPLE: INTERVENTION DEVELOPMENT AND PILOT RANDOMISED CONTROLLED TRIAL}

${ }^{1}$ Caroline Free* ${ }^{1}$ Ona McCarthy, ${ }^{3}$ Paula Baraitser, ${ }^{1}$ Rebecca French, ${ }^{1}$ Kaye Wellings, ${ }^{1}$ Karen Devries, ${ }^{1}$ Sujit Rathod, ${ }^{2}$ Susan Michie, ${ }^{2}$ Graham Hart, ${ }^{2}$ Julia Bailey. 'LSHTM, London, UK; ${ }^{2}$ UCL, London, UK; ${ }^{3}$ Kings College Hospital, London, UK

\subsection{6/sextrans-2016-052718.293}

Background/introduction Younger people bear the heaviest burden of sexually transmitted infections (STIs). The acceptability and feasibility of conducting a randomised controlled trial of safer sex support delivered by text message are not known.

Aim(s)/objectives To develop a safer sex intervention delivered by text messages for people aged 16-24. To assess the acceptability and feasibility of a randomised controlled trial.

Methods The intervention was developed based on evidence, behavioural theory, and user views. It was designed to reduce STIs by increasing correct treatment of STI, partner notification, condom use and STI testing. We conducted a pilot, randomised controlled trial with people aged 16-24 diagnosed with chlamydia or reporting unprotected sex with more than one partner in the last year. We conducted qualitative interviews.

Results Two hundred participants were randomised. We fully recruited early and achieved $81 \%$ follow up for our proposed primary outcome cumulative incidence of chlamydia at 12 months. Ninety-seven percent of messages sent were successfully delivered to participants' phones. Recipients reported that the 